Published in "Basic and Applied Ecology 33: 14-24, 2018"

which should be cited to refer to this work.

\title{
Estimating economic benefits of biological control of Ambrosia artemisiifolia by Ophraella communa in southeastern France
}

\author{
Raphaelle Mouttet $^{\mathrm{a}}$, Benno Augustinus ${ }^{\mathrm{b}}$, Maira Bonini ${ }^{\mathrm{c}}$, Bruno Chauvel $^{\mathrm{d}}$, \\ Nicolas Desneux ${ }^{\mathrm{e}}$, Emmanuel Gachet ${ }^{\mathrm{f}}$, Thomas Le Bourgeois ${ }^{\mathrm{g}}$, \\ Heinz Müller-Schärer ${ }^{\mathrm{h}}$, Michel Thibaudon ${ }^{\mathrm{i}}$, Urs Schaffner ${ }^{\mathrm{b}}, *$ \\ ${ }^{a}$ Anses, Unité Entomologie et Plantes invasives, CBGP, 755 avenue du campus Agropolis, CS30016, 34988 \\ Montferrier-sur-Lez, France \\ ${ }^{\mathrm{b}}$ CABI, Rue des Grillons 1, 2800 Delémont, Switzerland \\ ${ }^{\mathrm{c}}$ Department of Hygiene and Health Prevention - Hygiene and Public Health Service, Agenzia di Tutela della \\ Salute della Città Metropolitana di Milano/LHA ATS Città Metropolitana di Milano, Parabiago, MI, Italy \\ ${ }^{\mathrm{d}}$ Agroécologie, AgroSup Dijon, CNRS, INRA, Université Bourgogne Franche-Comté, 21000 Dijon, France \\ 'INRA (French National Institute for Agricultural Research), Université Côte d'Azur, CNRS, UMR 1355-7254 \\ Institute Sophia Agrobiotech, 06903 Sophia-Antipolis, France \\ ${ }_{\mathrm{f}}^{\mathrm{f}}$ Anses, Unité Expertise sur les risques biologiques, Laboratoire de la santé des végétaux, 7 rue Jean Dixméras, \\ 49044 Angers, France \\ ${ }^{\mathrm{g}}$ Cirad, UMR AMAP, TA A51/PS2, Boulevard de la Lironde, 34398 Montpellier, France \\ ${ }^{\mathrm{h}}$ University of Fribourg, Department of Biology, Pérolles, 1700 Fribourg, Switzerland \\ ${ }^{\mathrm{i}}$ French Network of Aerobiological Monitoring RNSA, Chemin de la Creuzille, 69690 Brussieu, France
}

\begin{abstract}
The North American common ragweed, Ambrosia artemisiifolia, which produces highly allergenic pollen, is invasive in different parts of the world, including Europe. In 2013, common ragweed in northern Italy was found attacked by another accidentally introduced species, the North American leaf beetle Ophraella communa, which is used for biological control of common ragweed in China. Since the establishment of $O$. communa, ragweed pollen concentrations in northern Italy have significantly dropped. Here we set out to estimate the potential economic benefits of establishment of $O$. communa in the Rhône-Alpes region in south-eastern France, where detailed data on the economic impact of common ragweed are available. Extrapolating from the change in airborne ragweed pollen concentrations in the Milan area, we estimated that establishment of $O$. communa in the Rhône-Alpes region will reduce the number of days with ragweed pollen concentrations at which sensitive people express symptoms by $50 \%$ and the medical costs due to common ragweed by $5.2-6.8 \mathrm{M} €$ annually. Our findings suggest
\end{abstract}

\footnotetext{
${ }^{*}$ Corresponding author.

E-mailaddresses: raphaelle.mouttet@anses.fr (R. Mouttet), b.augustinus@cabi.org (B. Augustinus), mbonini@ats-milano.it (M. Bonini), bruno.chauvel@inra.fr (B. Chauvel), nicolas.desneux@inra.fr (N. Desneux), emmanuel.gachet@anses.fr (E. Gachet), thomas.le_bourgeois@cirad.fr (T. Le Bourgeois), heinz.mueller@unifr.ch (H. Müller-Schärer), michel.thibaudon@wanadoo.fr (M. Thibaudon), u.schaffner@cabi.org (U. Schaffner).
} 
that investments of public funds are justified to conduct a complete assessment of the potential risks and benefits associated with the accidental establishment of $O$. communa in Europe.

(C) 2018 Gesellschaft für Ökologie. Published by Elsevier GmbH. All rights reserved.

Keywords: Ambrosia artemisiifolia; Biological control; Economics; Health

\section{Introduction}

Invasive alien plant species (IAPS) not only cause significant harm to biological diversity and ecosystem functioning (Vilà et al. 2011), they also induce direct economic impacts by affecting ecosystem services such as livestock production, water availability or human health (Pejchar \& Mooney 2009). To address a growing pressure for delivering sustainable IAPS management solutions, targeted management solutions need to be elaborated and their environmental and economic consequences assessed and communicated to decision-makers and other stakeholders (Hulme 2006; Müller-Schärer, Schaffner, \& the COST-SMARTER Task Force Ophraella 2017).

When selecting suitable IAPS management options, it is worth distinguishing between the likelihood of success of a control programme and its potential impact (Cock et al. 2015). The former addresses the implementation of the steps of an IAPS control programme and the anticipated reduction of the target weed, while the latter addresses the socioeconomic and environmental benefits of successful IAPS control. A key aspect regarding the impact of a sustainable IAPS management strategy is the relationship between the economic investment in the implementation of the management strategy and the expected economic benefits in case of a successful control of the target weed (Culliney 2005; Jetter 2005; Page \& Lacey 2006).

Classical biological control aims to reduce the IAPS' abundance below an economic or ecological threshold and/or slow down its spread by the introduction of one or a few specialist natural enemies from the weed's native range (Müller-Schärer \& Schaffner 2008). Usually, the introduction of specialist biological control agents is based on a decision process by competent authorities after careful evaluation of pre-release studies assessing the likelihood of non-target effects and impact of the agent, but in times of increased biological invasions (Seebens et al. 2017), more and more potential biological control agents are also accidentally introduced into regions where IAPS cause problems (Shaw et al. 2018) There is growing evidence that classical biological control, if successful, can play a major role in the sustainable IAPS management (Seastedt 2014) and that it is highly costeffective compared to other methods (Page \& Lacey 2006; De Lange \& van Wilgen 2010; van Wilgen et al. 2012). Most of this evidence comes from retrospective studies, or ex-post studies, that compared actual data on the costs of implementing the program, the impact of the IAPS as well as the reduction in impact due to classical biological control, and therefore tend to provide relatively accurate estimates of the cost-effectiveness of this approach (Culliney 2005).

In contrast to chemical or mechanical weed control, which often benefit directly those who supply them, the implementation of classical biological weed programs often requires a significant initial investment of public funds (Pannell 1994). Therefore, attempts have also been made to evaluate the likely benefits of a classical biological control program ex-ante, i.e. before or at an early stage of a biological control program, in order to assess whether the funding required for its implementation is likely to be justified. The few ex-ante studies that have been conducted so far also suggest that biological control programs have favourable benefit:cost ratios (Gurr \& Wratten 2000; Perrings, Williamson, \& Dalmazzone 2000; Culliney 2005; Jetter 2005). However, because their results depend on the accuracy of the various assumptions made a priori, they are usually subject to considerable uncertainty (Jetter 2005). This uncertainty may be reduced when the likelihood of success of the biological control approach can be extrapolated from experiences made in other parts of the invaded range, and when the weed's impact - and hence the potential savings - can be attributed to specific costs, e.g. to health costs that can be allocated to the target IAPS.

The North American plant species Ambrosia artemisiifolia L., common ragweed, was first recorded in Europe in the 19th century and started spreading in the late 1920s (Essl et al. 2015). Today it is widely distributed in Europe, with invasion hotspots in the Pannonian plain, the Balkans, northern Italy and around the Rhône valley in France (Šikoparija et al. 2016). While A. artemisiifolia is also an agricultural weed in Eastern Europe, the main concern regarding its economic impact in Europe is its large production of highly allergenic pollen that causes rates of sensitisation among Europeans in the invaded regions ranging from 10\% to 60\% (Burbach et al. 2009). Exposure to ragweed pollen induces allergic rhinitis and severe asthma, generating significant medical costs and reduced quality of life among the allergic population (D'Amato et al. 1998; Thibaudon, Hamberger, Guilloux, \& Massot 2010). Climate change is likely to increase spread and impact of A. artemisiifolia, posing a significant risk to society, even in countries presently not yet affected (Hamaoui-Laguel et al. 2015).

In 2013, the North American leaf beetle Ophraella communa LeSage, 1986 (Coleoptera, Chrysomelidae) was found to have accidentally established in northern Italy and southern Switzerland (Müller-Schärer et al. 2014). This beetle is 


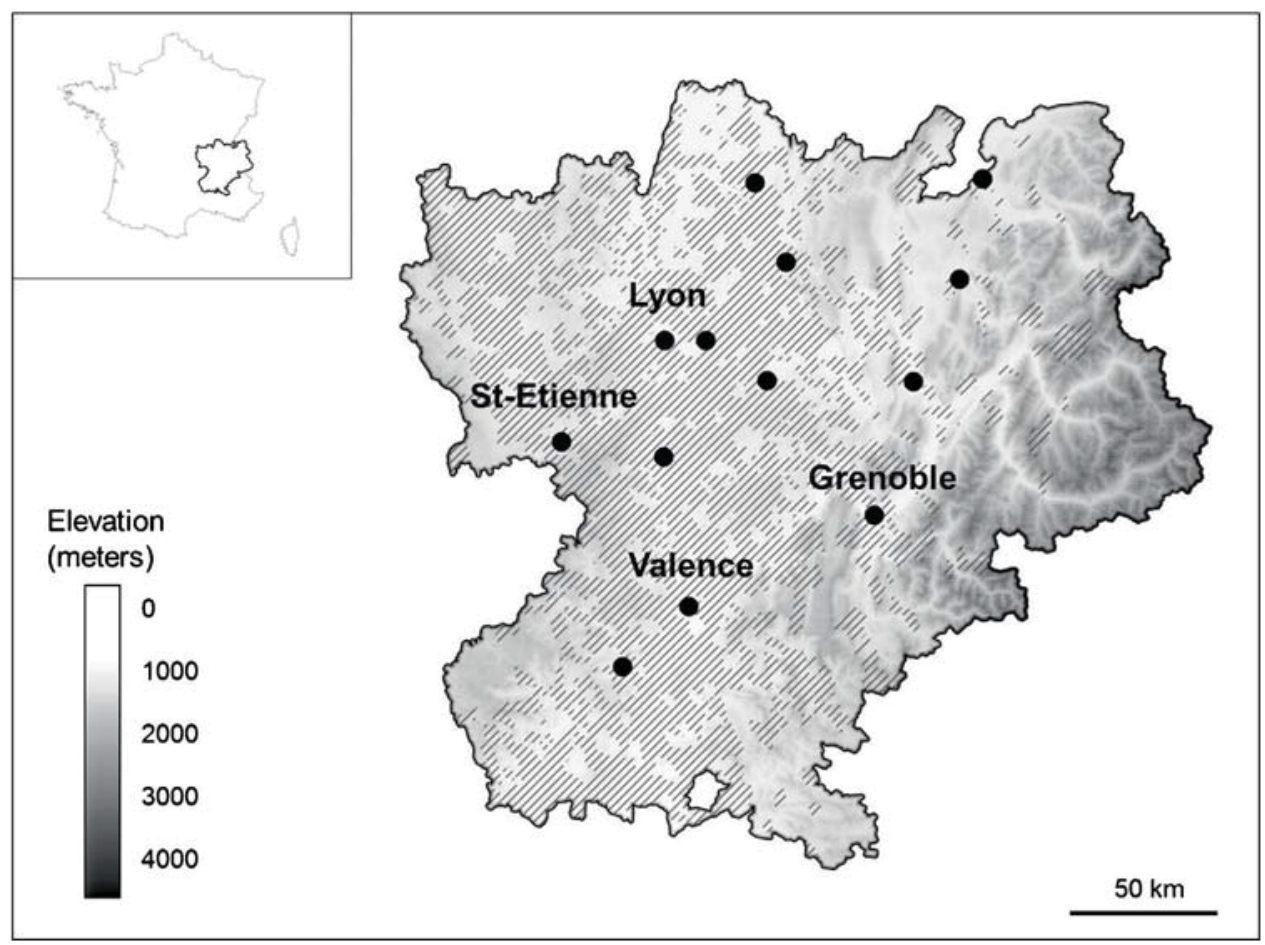

Fig. 1. The Rhône-Alpes region with location of pollen stations, distribution of ragweed at the municipal level (source: Observatoire des ambroisies), and elevation (source: Institut Géographique National, France). Black dots correspond to the thirteen pollen stations and hatching to the municipalities with confirmed presence of A. artemisiifolia.

an oligophagous beetle that is being used as a biological control agent against $A$. artemisiifolia in China (Guo et al. 2011), although no-choice tests under laboratory conditions revealed that it can complete its life-cycle on sunflower, Helianthus annuus L. (Palmer \& Goeden 1991). At sites in northern Italy where the beetle was present, up to $100 \%$ of the common ragweed plants were attacked, with damage levels high enough to cause complete defoliation and to prevent flowering and seed set in most ragweed plants (Müller-Schärer et al. 2014). Pollen monitoring studies in the Milan area revealed that since the establishment of $O$. communa ragweed pollen concentrations have dropped by approximately $80 \%$ (Bonini et al. 2015, 2016). Bonini et al. $(2015,2016)$ showed that the low amounts of airborne Ambrosia pollen observed in the Milan area in 2013 and 2014 could not be explained by meteorology. Moreover, insect exclosure experiments in northern Italy revealed that at the densities observed in 2014 and 2015 O. communa inflicted a high mortality and reduction in reproductive output of Ambrosia at the population level (Lommen et al. 2017a), further supporting the notion that the decrease in aerial Ambrosia pollen concentration in the Milan region is related to the presence of large numbers of O. communa. By 2016, the beetle had colonized almost the entire area in northern Italy invaded by common ragweed (Müller-Schärer et al. 2017).

To inform science-based decision processes about how to respond to a likely upcoming establishment of this accidentally introduced insect in other parts of Europe, risk assessments (Müller-Schärer et al. 2017; Lommen, Jolidon, Sun, Bustamante Eduardo, \& Müller-Schärer 2017b) should be combined with ex-ante studies to evaluate both the potential risks and benefits of an establishment of O. communa. Here we set out to estimate the potential effect of an establishment of $O$. communa on human health costs in the Rhône-Alpes region in France, which is bordering the Italian region invaded by $O$. communa. Capitalizing on the observed impact of $O$. communa on airborne ragweed pollen concentration in the Milan area and on the well-documented health costs related to common ragweed in the Rhône-Alpes region, we estimated to what extent a potential establishment of $O$. communa in the Rhône-Alpes region might reduce the health risks for the inhabitants of this region and hence the associated human health costs.

\section{Material and methods}

\section{Study area}

The Rhône-Alpes region lies in south-eastern France, covering an area of $43,700 \mathrm{~km}^{2}$ with approximately 6.5 million inhabitants. Its topography consists of two areas of high elevation (the Alps in the eastern part and the Massif Central mountains in the western part) divided by the Rhône Valley, which runs north-south (Fig. 1). The climate is mainly continental, characterized by cold winters and hot summers. The Rhône valley areas have the highest common ragweed 
infestation in France (Thibaudon, Šikoparija, Oliver, Smith, $\&$ Skjøth 2014) and, together with the Pannonian plain and northern Italy, one of the highest common ragweed infestations in Europe (Šikoparija et al. 2016).

\section{Estimating the impact of $O$. communa on airborne Ambrosia pollen concentrations}

Daily ragweed pollen concentrations for the RhôneAlpes region for the period 2008-2015 were provided by the French National Aerobiological Monitoring Network (RNSA) from thirteen pollen stations (Ambérieu, Annecy, Annemasse, Bourg-en-Bresse, Bourgoin-Jallieu, Chambéry, Coux, Genas, Grenoble, Lyon, Roussillon, Saint-Etienne, Valence) located across the Rhône-Alpes region (Fig. 1). For the Milan region, daily ragweed pollen concentrations for the period from 2008 to 2012 (before the detection of O. communa) and from 2013 to 2015 (when high densities of $O$. communa were recorded) were provided by the Local Health Authority of Milan 1 (now Local Health Authority of Milan Città Metropolitana) from three pollen stations (Legnano, Magenta and Rho) located in the north-western area of the Province of Milan in northern Italy. In both regions, atmospheric concentrations of Ambrosia pollen are monitored using volumetric spore traps of the Hirst design (Hirst 1952). Each year, the period covered by the data ran from July 15 to October 15 . The amount of airborne pollen was expressed as the number of ragweed pollen grains per cubic meter of air and day.

The potential impact of O. communa on airborne Ambrosia pollen concentrations in the Rhône-Alpes region was assessed by transferring the observed relative change in airborne Ambrosia pollen concentration in the Milan area from years before to years after establishment of $O$. communa to the conditions in the Rhône-Alpes region. Specifically, we estimated the pollen reduction in the Milan area by calculating the relative difference between the two time-integrated pollen load curves averaged over the three Italian stations for the periods 2008-2012 and 2013-2015. The Milan area is mainly situated below $200 \mathrm{~m}$ where $O$. communa can complete 3-4 generations per year. We thus adjusted the expected impact in the Rhône-Alpes region by calculating the percentage of Ambrosia populations that grow at an altitude that allows $O$. communa to complete at least 3 generations per year. Information on the altitudinal threshold in southern Europe below which $O$. communa can complete at least 3 generations per year was collected from a field cage experiment set up along an altitudinal gradient in the southern Alps (see Supplementary Appendix A: Fig. 1). The altitudinal distribution of common ragweed in the Rhône-Alpes region was assessed from all geo-referenced Ambrosia records collected by the French National Federation of Botanical Conservatories (FCBN). As the impact of $O$. communa on common ragweed mainly builds up during the third generation of $O$. communa in late summer, we predicted that Ambrosia popu- lations below the altitudinal threshold determined in the field experiment will experience the same impact as populations in the Milan area, while populations above a certain altitudinal threshold are expected to escape from significant impact by O. communa.

\section{Estimating the impact of $O$. communa on allergic risk}

RNSA defined an allergic risk index (RAEP; 'risque allergique d'exposition aux pollens'; allergy risk when being exposed to pollen) with six risk levels according to the daily ragweed pollen exposure (see Supplementary Appendix A: Table 1; Thibaudon, Oliver, \& Cheynel 2008). The pollen risk threshold $\mathrm{RAEP}=3$ (daily abundance of $\geq 6$ grains $\times \mathrm{m}^{-3} \times$ day $^{-1}$ ) corresponds to the level of pollen concentration at which $100 \%$ of ragweed sensitized people express symptoms in the Rhône-Alpes region (ORS RhôneAlpes 2015). As such, the number of days with RAEP $\geq 3$ provides an estimate of the allergenic risk of common ragweed over the season. Daily airborne pollen data from the Rhône-Alpes region from 2008 to 2015 were therefore converted to the number of days with RAEP $\geq 3$ in order to assess the allergic risk in the actual situation and in a scenario where O. communa is present.

\section{Estimating the impact of $O$. communa on health costs}

Since 2007, the Regional Health Agency, in association with the National Aerobiological Monitoring Network, has been collecting data on the annual health costs of ragweed allergy in the Rhône-Alpes region (ORS Rhône-Alpes 2011, 2012, 2013,2015). The costs are based on the consumption of medical care and medical goods by persons affiliated to the general health insurance scheme and include costs related to allergy medication, doctor consultation, allergy tests used, oral desensitization treatments and on sick leave when linked to the prescription of anti-allergic drugs (see Supplementary Appendix A: Table 2 for further explanations). These assessments include a low-cost estimate which accounts for the population that is most likely affected by ragweed allergy as well as a high-cost estimate accounting for the whole regional population (ORS Rhône-Alpes 2012). The relation between the annual allergic risk (expressed as the cumulated number of days with RAEP $\geq 3$ over the 13 stations) and the estimated annual health costs in the observed scenario were examined by a linear regression model with a logarithmic transformation of the estimated health costs. This model was used to estimate annual health costs in the scenario with a decrease in pollen emission after the establishment of O. communa. All analyses were done using software $\mathrm{R}$ version 3.2.3 (R Core Team 2015). 


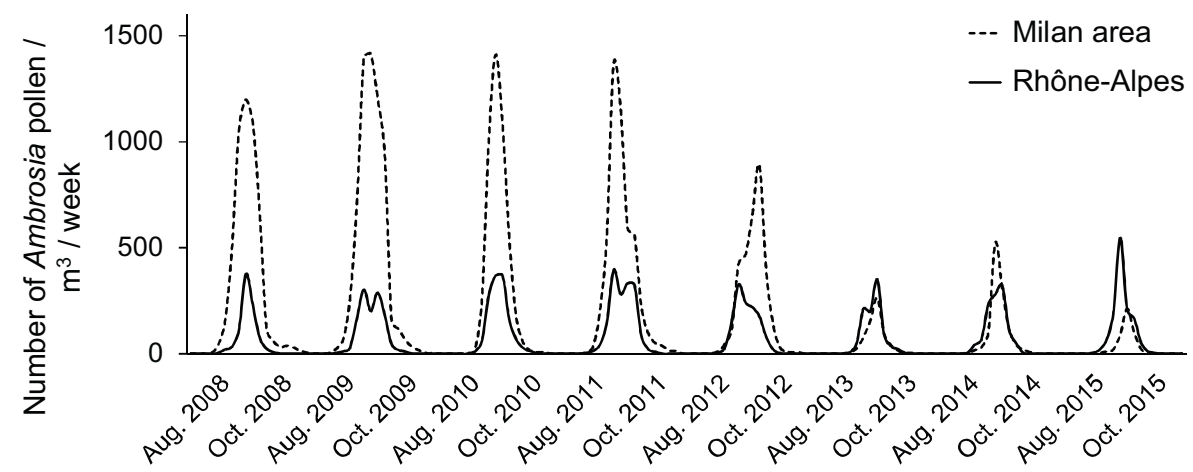

Fig. 2. Comparative trends of ragweed airborne pollen concentration in the Milan area (mean over three pollen stations; data provided by the Local Health Authority of Milan Città Metropolitana) and in the Rhône-Alpes region (mean over thirteen pollen stations; data provided by French National Aerobiological Monitoring Network) between 2008 and 2015. Given are weekly numbers of Ambrosia pollen per m ${ }^{3}$ during the pollen season (August-October) of each year.

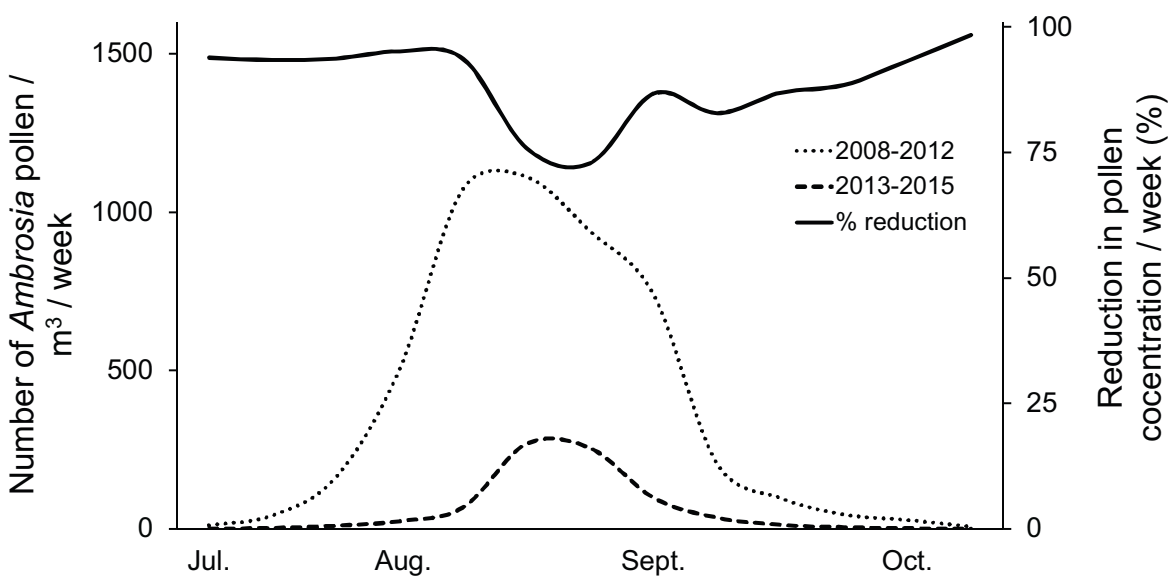

Fig. 3. Phenology of airborne pollen concentration from 2008 to 2012 (before the detection of $O$. communa) and 2013 to 2015 in the Milan area and percent reduction in airborne pollen concentration after the detection of $O$. communa. Curves (smoothed with moving average functionality) of airborne pollen concentrations are based on mean $\pm \mathrm{SE}$ weekly numbers of Ambrosia pollen per $\mathrm{m}^{3}$ during the years before and after detection of $O$. communa, respectively. Data were provided by the Local Health Authority of Milan Città Metropolitana.

\section{Results}

\section{Estimating the impact of $O$. communa on airborne Ambrosia pollen concentrations}

Seasonal appearance of airborne ragweed pollen is similar in the Rhône-Alpes region and the Milan area, but the pollen concentration before the establishment of $O$. communa in the Milan area was higher than in the Rhône-Alpes region (Fig. 2). In both cases, the observed aerial pollen concentration dynamics follows the flowering phenology of $A$. artemisiifolia and known patterns of pollen emission in other regions with high Ambrosia infestations (Šikoparija et al. 2016).

In the Milan area, an $85.9 \%$ decrease in pollen emission was observed between the periods 2008-2012 and 2013-2015 (Fig. 3). No such reduction was detected in the Rhône-Alpes region or in any other part of Europe (Šikoparija et al. 2016), where the biological control agent was absent, suggesting that the reductions in Milan area were due to the biological control agent. After an examination of airborne pollen data from the Milan area, a constant reduction in airborne pollen concentration by $85.9 \%$ across time and space was chosen to extrapolate the reduction observed in northern Italy to the study area. This constant reduction level was chosen given that (i) it corresponds to the average reduction in airborne pollen concentration observed from the period 2008-2012 to 2013-2015 in the Milan area (Bonini et al. 2015, 2016), that (ii) the reduction in airborne Ambrosia pollen concentration was relatively consistent across the pollen season (Fig. 3) and assuming that (iii) O. communa, once it will have established in the Rhône-Alpes region, will exhibit similar population dynamics (and impact on $A$. artemisiifolia) as in northern Italy.

The field study set up along an altitudinal gradient north of the Milan area in Italy (see Supplementary material for a description of methods and results) revealed that time from oviposition to adult emergence increased from approximately 17 days in the Milano area to approximately 20 days at $250 \mathrm{~m}$ a.s.l., approximately 23 days at 480 and $700 \mathrm{~m}$ a.s.1., and 


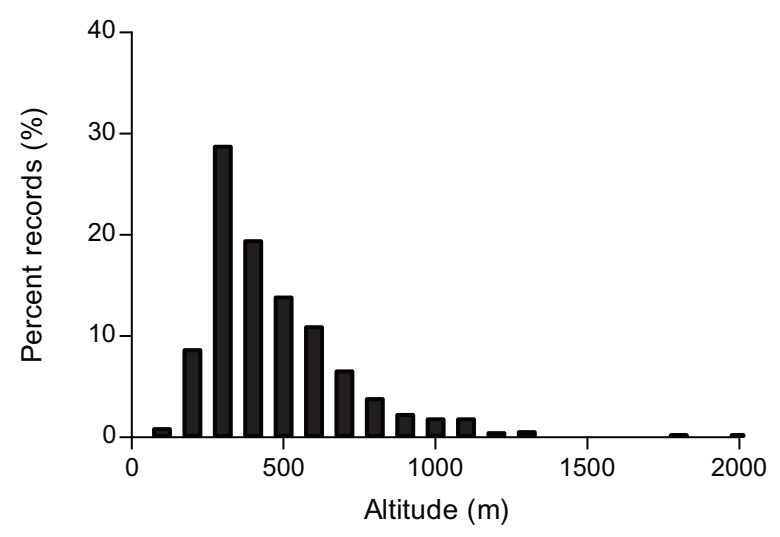

Fig. 4. Altitudinal distribution of common ragweed occurrence data in the Rhône-Alpes region ( $n=1340$; data from the French Network of Aerobiological Monitoring).

37 days at $1,230 \mathrm{~m}$ a.s.l. (see Supplementary Appendix A: Fig. 1). Based on the development threshold and cumulative degree days determined in this field study (Augustinus, unpubl. results) and from the literature (Zhou, Guo, Chen, \& Wan 2010), these results indicate that $O$. communa can complete at least three generations up to $700 \mathrm{~m}$ above sea level in the Rhône-Alpes region. Based on the altitudinal distribution of 1340 records of common ragweed populations in the Rhône-Alpes region (Fig. 4), 88.7\% of the common ragweed populations found in the Rhône-Alpes region are found $\leq 700 \mathrm{~m}$ a.s.l. and are therefore expected to be damaged by $O$. communa to a similar extend as those in the Milan area. Considering the altitudinal distribution of Ambrosia populations in the Rhône-Alpes region, the reduction in airborne ragweed pollen concentration due to $O$. communa is estimated at $85.9 \% \times 0.887=76.2 \%$.

\section{Estimating the impact of $O$. communa on allergic risk}

Between 2008 and 2015, there were on average 24 days per year in the Rhône-Alpes region with RAEP $\geq 3$. A 76.2\% decrease in airborne ragweed pollen concentrations would reduce the number of days with RAEP $\geq 3-12$ days $(50 \%$ reduction; Fig. 5).

\section{Estimating the impact of O. communa on health costs}

In the Rhône-Alpes region, the annual number of days with $\mathrm{RAEP} \geq 3$ proved to be a significant predictor of the logtransformed low and high estimates of annual health costs, but the model fit was relatively modest (low-cost estimate: adjusted r-squared 0.504, $\mathrm{p}=0.0292$; high-cost estimate: adjusted r-squared $=0.417, \mathrm{p}=0.0498$; see Supplementary Appendix: Table 3). Based on this relationship, we estimated annual health costs in the scenario with a $76.2 \%$ decrease in pollen emission and compared it to the actual health costs measured. In the observed situation, the mean annual health costs in the period from 2008 to 2015 were estimated to range from $€ 9.70$ million (low estimate) to $€ 14.04$ million (high estimate), while they were estimated to range from $€ 4.47$ million to $€ 7.21$ million in a situation with a $76.2 \%$ decrease in airborne pollen concentrations (Fig. 6). Thus, the establishment of $O$. communa in the Rhône-Alpes region is expected to lead to annual savings in health costs of $€ 5.23$ million (low estimate) to $€ 6.83$ million (high estimate) in this region.

\section{Discussion}

\section{Economic benefits of an establishment of $O$. communa in the Rhône-Alpes region}

The estimated reduction in airborne pollen concentration is based on the assumption that most of the airborne pollen in the Rhône-Alpes region is produced locally or regionally and that $O$. communa will exhibit a similar impact on ragweed pollen production in areas below $700 \mathrm{~m}$ a.s.l. as in the Milan region. In the absence of wind, pollen collection at the regional pollen stations is between 06:00 and 14:00, suggesting that the pollen are of local origin (Laaidi \& Laaidi 1999). However, the Rhône Valley is characterized by sometimes strong winds from the south and also from the north. The area invaded by common ragweed that is situated south of the Rhône-Alpes region also appears suitable for O. communa (Sun et al. 2017), suggesting that the amount of pollen entering the Rhône-Alpes region from the south will also drop once O. communa has established in south-eastern France. The climatic conditions north of the Rhône-Alpes region appear to be less suitable for $O$. communa to complete at least 3 generations (Sun et al. 2017), but common ragweed densities and airborne pollen concentrations are lower than in or south of the Rhône-Alpes region (Šikoparija et al. 2016).

Our field studies in the Milan region revealed that temperature and air humidity are key abiotic factors affecting within-season population build-up of O. communa, as they influence egg hatching rate, larval development rate and generation length (Augustinus, unpubl. results). We also found that significant impact on ragweed pollen and seed production in the Milan region only becomes apparent from the third generation onwards (Lommen et al. 2017a). We acknowledge that all our estimates of the current impact of $O$. communa on ragweed pollen concentration in the Milan region and on its predicted impact on ragweed pollen concentration and on the allergic risk in the Rhône-Alpes region are associated with a level of uncertainty. For example, while our field studies suggest that $O$. communa can complete three generations in the lower parts of the Rhône-Alpes region, it remains to be shown whether the third generation of $O$. communa will defoliate the plants before they start producing male flowers. Nevertheless, we argue that the uncertainty of our predictions regarding the impact of biological control is 


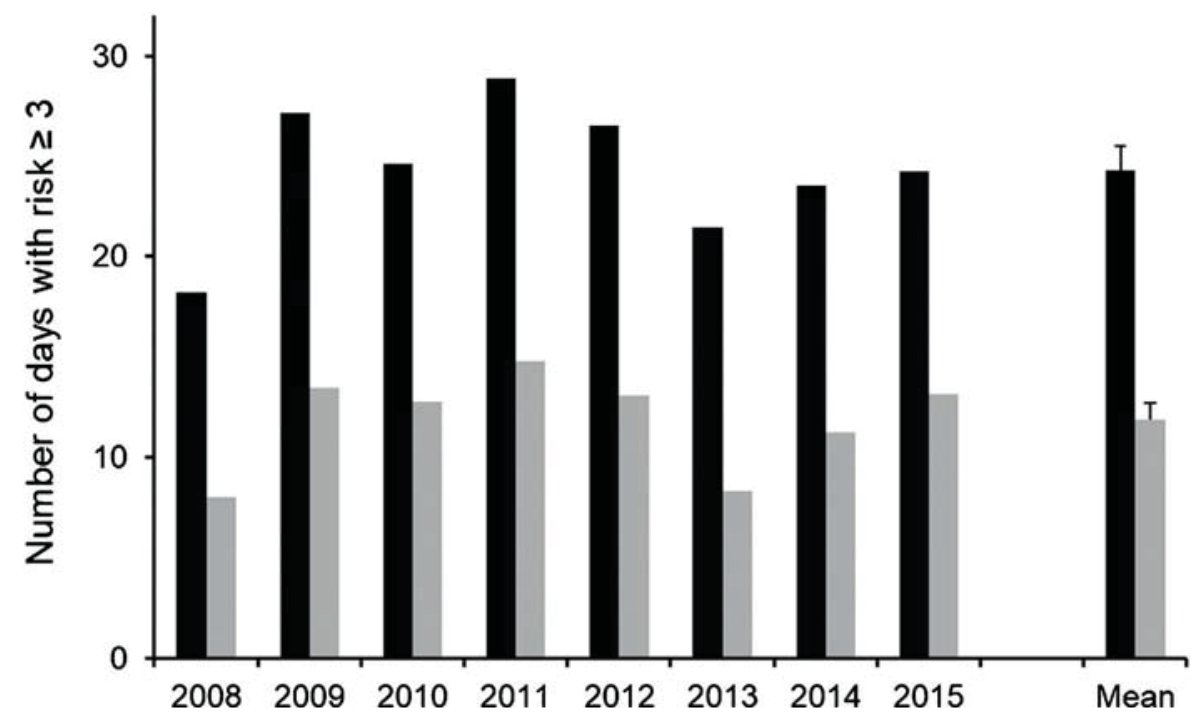

Fig. 5. Allergic risk index (expressed as the annual number of days with 'risque allergique d'exposition aux pollens'; RAEP) $\geq 3$ for the period from 2008 to 2015, based on the actual aerial pollen concentrations measured (black) and on a scenario with a $76.2 \%$ decrease in pollen concentrations (grey). Average allergic risks for the whole period are expressed as mean $\pm \mathrm{SE}$.

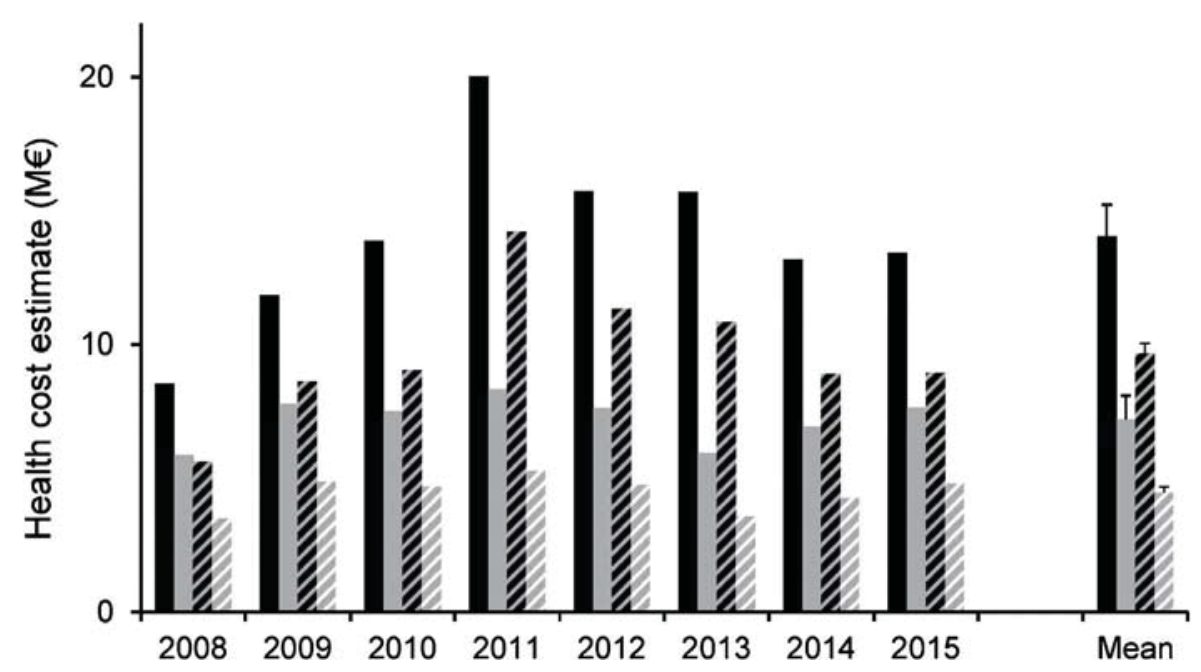

Fig. 6. Health costs estimates (expressed in $\mathrm{M} €$ ) in the Rhône-Alpes region from 2008 to 2015 in the actual situation (black) and in a scenario with a $76.2 \%$ reduction in airborne pollen concentrations (grey). The high cost estimates (solid histograms) account for the whole regional human population, while the low cost estimates (hatched histograms) account for the population that is most likely affected by ragweed allergy (ORS Rhône-Alpes, 2012). Average health costs estimates for the whole period are expressed as mean \pm SE.

relatively low, compared to other ex-ante studies evaluating the likely impacts of a classical biological control programs (Gurr \& Wratten 2000; Perrings et al. 2000; Culliney 2005; Jetter 2005). The number of days with pollen risk $\geq 3$, i.e. the number of days where ragweed sensitized people express symptoms, is a significant explanatory variable of the health costs related to ragweed allergies in the Rhône-Alpes region (ORS Rhône-Alpes 2015), but the model fit (approx. 50\%) is relatively modest. Our estimates of the health costs caused by common ragweed in the Rhône-Alpes region are based on detailed data collected from the general health insurance scheme, but not all costs may be due to ragweed-caused allergies, nor are all health impacts caused by common ragweed included in these numbers. Anti-allergic drugs sold during the common ragweed flowering period might have been used for purposes other than ragweed allergies, which would lead to an overestimation of the costs related to ragweed allergy. However, in order to link the health costs as closely to ragweed allergy as possible, patients were selected on the basis of reimbursements of anti-allergic medicaments for which a peak of consumption was observed in September, i.e. during the peak of airborne Ambrosia pollen concentration. In southern Europe, very few plant species with allergenic pollen flower at the same time as common ragweed, and the two other ragweed species (Ambrosia trifida and A. psilostachya) are absent or very rare in this area. For example, the flowering phenology of mugwort species, such as Artemisia vulgaris L., is approximately 3 weeks earlier than that of common rag- 
weed, and the season of airborne Artemisia pollen ends during the second half of August (D'Amato et al. 1998). Accordingly, in the Milan area mugwort monosensitized patients have symptoms before monosensitized ragweed patients and they stop suffering before monosensitized ragweed patients do (Bottero et al., unpubl. results).

On the other hand, persons suffering from ragweed allergy might not have been included in the costs because they may have taken precautions or got a prescription for an antiallergen earlier in the year, which would underestimate the actual costs inflicted by common ragweed. Also, sufferers may not have sought medical help and just waited for the symptoms to pass. Thus, there would have been no medical costs, but potentially costs in work time lost. We are therefore confident that selecting patients on the basis of reimbursements of anti-allergic medicaments for which consumption peaks in September is a realistic approach to estimate health costs linked to common ragweed.

Based on the data collected by RNSA, ragweed allergies affected in 2013 some 204,186 people in the Rhône-Alpes region, with a total cost of $€ 15.7$ million or an average costs of approximately $€ 77$ per patient (ORS Rhône-Alpes 2015). This average cost estimate is at the lower end of what is reported in the literature. Reported medical costs of $A$. artemisiifolia in Europe range from $€ 8$ to $€ 8000$ (median $€ 565)$ per patient and year, depending on the type of medication and the country (Bullock et al. 2012). Medication costs vary considerably across countries in Europe, but the costs documented for the Rhône-Alpes region are also at the lower end of the range reported from France (€26-€386 reimbursement; Bullock et al. 2012). In a recent review of European studies on the costs associated with allergic respiratory diseases, median direct (treatment) and indirect (primarily due to absenteeism) costs for seasonal allergic rhinitis were calculated to amount to $€ 791$ per patient and year (Linneberg et al. 2016). This suggests that the estimates of a reduction in health costs in the Rhône-Alpes region due to a potential establishment of $O$. communa are conservative and that the actual savings may be considerably higher. We therefore propose that a potential establishment of the accidentally introduced $O$. communa may indeed generate significant economic benefits in terms of savings in health costs.

\section{Assessment of the benefits and costs of biological control of common ragweed in Europe}

In an economic impact assessment of weed biological control undertaken in Australia between 1903 and 2005, Page and Lacey (2006) estimated a reduction of approximately 350,000 people suffering from common ragweed-induced hay-fever and an economic benefit of approximately AUS $\$ 23.85$ per patient (expenditure on medicine) due to biological control of common ragweed. With an estimated cost of AUS \$625,000 for implementing the biological control pro- gram, this resulted in a benefit:cost ratio of 103.7:1 for the biological control of common ragweed in Australia by 2005. It should be noted though that the common ragweed project benefited from releases made in the frame of the biological control program against Parthenium hysterophorus L., a close relative of common ragweed that also produces highly allergenic pollen. The biological control program against $P$. hysterophorus in Australia began in 1977 and exploration and new releases finished in 2004. In total, it is estimated to have cost AUS\$11.0 million (Page \& Lacey 2006). By 2005, key outcomes achieved from the Parthenium biocontrol program included annual savings of AUS $\$ 380,000$ productivity benefit in sown pasture, AUS $\$ 986,000$ productivity benefit in native pasture, and AUS $\$ 8.0$ million benefit in reduced medical expenses. Despite the higher project costs, the benefit:cost ratio of the Parthenium biocontrol program was already 7.2:1 by 2005 (Page \& Lacey 2006) and continues to increase.

The limited number of studies estimating the benefit:cost ratio of classical biological weed control ex-ante, i.e. before the project is launched or at an early stage of the project, show quite favourable results (Gurr \& Wratten 2000; Culliney 2005). However, most ex-ante studies rely on some estimates of the probable success of the proposed program (Gurr \& Wratten 2000). This is particularly problematic in those cases where the biological control programs are based on new introductions of biological control agents that have not been used anywhere else (Gurr \& Wratten 2000). In the case of $O$. communa, both scenarios that facilitate the estimation of probable success are given; it is already used as a biological control agent of common ragweed in China (from where unfortunately no economic benefit:cost analyses are available), and it has been accidentally introduced into Europe, the region where biological control should be implemented. The fact that the establishment of $O$. communa in Northern Italy allows for an assessment of its population dynamics and impact under similar biotic and abiotic conditions as in the target region in the Rhône-Alpes region is expected to increase the robustness of the predictions of our ex-ante study.

To estimate the benefit:cost ratio of biological control of $A$. artemisiifolia by $O$. communa for the Rhône-Alpes region, we assumed that the overall costs for conducting the risk assessment for $O$. communa (see below) are comparable to those of the common ragweed program in Australia (AUS\$625,000 in $2005=$ approx. $€ 380,000$; Page \& Lacey 2006), which also benefited from previous biocontrol programs (see above). On this basis, five years with high $O$. communa densities would already lead to a benefit:cost ratio of 69:1 using the low estimates ( $€ 5.23$ million $\times 5 / € 0.38$ million) and of $90: 1$ using the high estimates for annual health costs (€6.83 million $\times 5 / € 0.38$ million). The predicted benefit:cost ratio of a biological control program against $A$. artemisiifolia using $O$. communa in the Rhône-Alpes region is comparable to that calculated for Australia (Page \& Lacey 2006), despite the fact that this French region is approximately five times smaller than the area invaded in Australia (Julien, McFadyen, \& Cullen 2012). Considering that $A$. artemisiifolia has a much 
broader distribution in Europe (Šikoparija et al. 2016), the European-wide economic benefits of implementing biological control against common ragweed would be significantly higher than in Australia.

\section{Using accidentally introduced natural enemies for biological control of invasive plant species}

As a consequence of globalization, biological invasions have greatly increased over the past decades, and there is no evidence for a slowing down of new introductions (Seebens et al. 2017). In this process, an increase of accidentally introduced natural enemies of IAPS has been reported, including species that are used or considered for use as biological control agents elsewhere (Shaw et al. 2018). In general, the handling and relocation of an accidentally introduced exotic organism, be it a biocontrol agent or not, requires permission from national competent authorities, but such organisms usually lack a rigorous risk analysis for the target region. Hence, biological control programs assessing the potential risks and benefits of accidentally introduced biological control candidates also require public funding to collect all information needed for a science-based decision on whether introduction of such organisms should be considered a fortunate coincidence or a threat (Müller-Schärer et al. 2014, 2017). The costs tend to be smaller since the host-range testing can build on previous studies done for other regions where the organism was considered for biological control (in the case of $O$. communa, e.g. Palmer \& Goeden 1991; Dernovici, Teshler, \& Watson 2006; Zhou et al. 2011).

Risk assessment studies with $O$. communa in Europe started within the frame of a European project (EU-COST Action on Sustainable Management of A. artemisiifolia in Europe, 2012-2016), and first results indicate that this beetle poses little risk to commercially grown sunflowers, which are harvested in late summer, and to native endangered plant species (Lommen et al. 2017b; Müller-Schärer et al. 2017). However, adult feeding may well occur on sunflower grown as ornamentals or used as green manure which still grow late in the year (Müller-Schärer et al. 2017). Based on the assessment of the potential benefits of biological control of common ragweed in the Rhônes-Alpes, we propose that investments of public funds to finalize the risk assessment of O. communa for Europe and, provided the non-target risks are acceptable, to redistribute the biological control candidate across the heavily infested regions in Europe are economically justified. Moreover, investments in an inundative biological control approach, which builds on mass-rearing and mass-release of O. communa as practiced in China (Zhou et al. 2014), should also be considered, particularly in regions that are heavily invaded by common ragweed, but that are climatically less suitable for a rapid population build-up of $O$. communa in early summer.

\section{Conclusions}

Biological control is a key strategy to manage widely established IAPS, given the scale of the infestation and the costs of applying other management options such as chemical or mechanical control (Culliney 2005). When IAPS impact human well-being directly, biological control programs are particularly likely to remain cost-effective (Seastedt 2014). Biological control of common ragweed has been considered in Europe since the 1960s, and various biological control candidates have been prioritized over the years (Gerber et al. 2011). Because O. communa can complete its life-cycle on sunflower under contained conditions, this species was neither proposed for field release in Australia (Palmer \& Goeden 1991), nor was it listed as a prioritized biological control candidate for Europe (Gerber et al. 2011). Yet, our findings suggest that $O$. communa has the potential to significantly reduce economic costs incurred by common ragweed, and that it is justified to invest in thorough risk assessment studies to assess its suitability for biological control of common ragweed in Europe. Provided that no action is taken to slow down the spread and population build-up of $O$. communa (ANSES 2015), the calculations made in this paper should become soon verifiable.

\section{Acknowledgements}

Urs Schaffner was supported by CABI with core financial support from its member countries (see http://www.cabi.org/about-cabi/who-we-work-with/keydonors/).

\section{References}

ANSES. (2015). Evaluation des risques pour la santé des végétaux liés à l'introduction accidentelle ou en tant qu'agent de lutte biologique, d'Ophraella communa, un insecte ravageur de l'ambroisie à feuilles d'armoise.. https://www.anses.fr/fr/system/files/SANTVEG2014SA0199R a.pdf. (Accessed 20 December 2016)

Bonini, M., Šikoparija, B., Prentovic, M., Cislaghi, G., Colombo, P., Testoni, C., et al. (2015). Is the recent decrease in airborne Ambrosia pollen in the Milan area due to the accidental introduction of the ragweed leaf beetle Ophraella communa? Aerobiologia, 31, 499-513.

Bonini, M., Šikoparija, B., Prentovic, M., Cislaghi, G., Colombo, P., Testoni, C., et al. (2016). A follow-up study examining airborne Ambrosia pollen in the Milan area in 2014 in relation to 
the accidental introduction of the ragweed leaf beetle Ophraella communa. Aerobiologia, 32, 371-374.

Bullock, J., Chapman, D., Schaffer, S., Roy, D., Girardello, M., Haynes, T., et al. (2012). Assessing and controlling the spread and the effects of common ragweed in Europe (ENV.B2/ETU/2010/0037). European Commission. Final Report.

Burbach, G. J., Heinzerling, L. M., Edenharter, G., Bachert, C., Bindslev-Jensen, C., Bonini, S., et al. (2009). Ragweed sensitization in Europe - GA(2)LEN study suggests increasing prevalence. Allergy, 64, 664-665.

Cock, M. J. W., Day, R. K., Hinz, H. L., Pollard, K. M., Thomas, S. E., Williams, et al. (2015). The impacts of some classical biological control successes. CAB Reviews, 10(42), 1-58.

Culliney, T. W. (2005). Benefits of classical biological control for managing invasive plants. Critical Reviews in Plant Sciences, 24, 131-150.

D’Amato, G., Spieksma, F. T. M., Licardi, G., Jager, S., Russo, M., Kontou-Fili, K., et al. (1998). Pollen-related allergy in Europe. Allergy, 53, 567-578.

De Lange, W. J., \& van Wilgen, B. W. (2010). An economic assessment of the contribution of weed biological control to the management of invasive alien plants and to the protection of ecosystem services in South Africa. Biological Invasions, 12, 4113-4124.

Dernovici, S. A., Teshler, M. P., \& Watson, A. K. (2006). Is sunflower (Helianthus annus) at risk to damage from Ophraella communa, a natural enemy of common ragweed (Ambrosia artemisiifolia)? Biocontrol Science and Technology, 16, 669-686.

Essl, F., Biro, K., Brandes, D., Broennimann, O., Bullock, J. M., Chapman, D. S., et al. (2015). Biological flora of the British Isles: Ambrosia artemisiifolia. Journal of Ecology, 103, 1069-1098.

Gerber, E., Schaffner, U., Gassmann, A., Hinz, H. L., Seier, M., \& Müller-Schärer, H. (2011). Prospects for biological control of Ambrosia artemisiifolia in Europe: Learning from the past. Weed Research, 51, 559-573.

Guo, J.-Y., Zhou, Z.-S., Zheng, X.-W., Chen, H.-S., Wan, F.-H., \& Luo, Y.-H. (2011). Control efficiency of leaf beetle, Ophraella communa, on the invasive common ragweed, Ambrosia artemisiifolia, at different growing stages. Biocontrol Science and Technology, 21, 1049-1063.

Gurr, G., \& Wratten, S. D. (2000). Biological control: Measures of success. Dordrecht, The Netherlands: Kluwer Academic Publishers., $437 \mathrm{p}$.

Hamaoui-Laguel, L., Vautard, R., Liu, L., Solmon, F., Viovy, N., Khvorosthyanov, D., et al. (2015). Effects of climate change and seed dispersal on airborne ragweed pollen loads in Europe. Nature Climate Change, 5, 766-771.

Hirst, J. M. (1952). An automatic volumetric spore trap. Annals of Applied Biology, 39, 257-265.

Hulme, P. E. (2006). Beyond control: Wider implications for the management of biological invasions. Journal of Applied Ecology, 43, 835-847.

Jetter, K. (2005). Economic framework for decision making in biological control. Biological Control, 35, 348-357.

Julien, M. H., McFadyen, R. E., \& Cullen, J. M. (2012). Biological control of weeds in Australia. Melbourne, Victoria, Australia: CSIRO Publishing., $619 \mathrm{p}$.
Laaidi, K., \& Laaidi, M. (1999). Airborne pollen of Ambrosia in Burgundy (France) 1996-1997. Aerobiologia, 15, 65-69.

Linneberg, A., Dam Petersen, K., Hahn-Pedersen, J., Hammerby, E., Serup-Hansen, N., \& Boxall, N. (2016). Burden of allergic respiratory disease: a systematic review. Clinical and Molecular Allergy, 14, 12.

Lommen, S. T. E., Augustinus, B. A., Schaffner, U., MüllerSchärer, H., the COST-SMARTER Task Force Ophraella, \& the COST-SMARTER Task Force Population Dynamics. (2017). Development and impact of Ophraella communa in Europe. Notiziario della Societü Botanica Italiana, 1, 111-112.

Lommen, S. T. E., Jolidon, E. F., Sun, Y., Bustamante Eduardo, J. I., \& Müller-Schärer, H. (2017). An early suitability assessment of two exotic Ophraella species (Coleoptera: Chrysomelidae) for biological control of invasive ragweed in Europe. European Journal of Entomology, 114, 160-169.

Müller-Schärer, H., \& Schaffner, U. (2008). Classical biological control: Exploiting enemy escape to manage plant invasions. Biological Invasions, 10, 859-874.

Müller-Schärer, H., Lommen, S. T. E., Rossinelli, M., Bonini, M., Boriani, M., Bosio, G., et al. (2014). Ophraella communa, the ragweed leaf beetle, has successfully landed in Europe: Fortunate coincidence or threat? Weed Research, 54, 109-119.

Müller-Schärer, H., Schaffner, U., \& the COST-SMARTER Task Force Ophraella. (2017). COST-SMARTER and risk assessment of Ophraella communa. Notiziario della Società Botanica Italiana, 1, 105-107.

ORS Rhône-Alpes. (2011). Deuxième rapport sur l'ambroisie en région Rhône-Alpes: Analyse des données environnementales et médico-économiques. , 72 p. http://wd043.lerelaisinternet.com/pdf/Ambroisie2.pdf. (Accessed 20 January 2018)

ORS Rhône-Alpes. (2012). Troisième rapport sur l'ambroisie en région Rhône-Alpes: Analyse des données environnementales et médico-économiques. http://wd043.lerelaisinternet.com/pdf/Ambroisie3.pdf. (Accessed 20 January 2018)

ORS Rhône-Alpes. (2013). Quatrième rapport sur l'ambroisie en région Rhône-Alpes: Analyse des données environnementales et médico-économiques. http://www.pieros.org/wp-content/uploads/2016/05/Etude1617 psante.pdf. (Accessed 20 January 2018)

ORS Rhône-Alpes. (2015). Rapport sur l'ambroisie en région Rhône-Alpes: Analyse des données environnementales et médico-économiques 2013 et 2014.. http://www.pieros.org/wp-content/uploads/2017/04/pieros1982 .pdf. (Accessed 20 January 2016)

Page, A. R., \& Lacey, K. L. (2006). Economic impact assessment of Australian weed biological control. Adelaide: CRC for Australian Weed Management., 151 p.

Palmer, W. A., \& Goeden, R. D. (1991). The host range of Opheraella communa Lesage (Coleoptera: Chrysomelidae). The Coleopterists Bulletin, 45, 115-120.

Pannell, D. J. (1994). Economic justification for involvement in weed management: A catalogue of market failures. Plant Protection Quarterly, 9, 131-137.

Pejchar, L., \& Mooney, H. A. (2009). Invasive species, ecosystem services and human well-being. Trends in Ecology and Evolution, 24, 497-504. 
Perrings, C., Williamson, M., \& Dalmazzone, S. (2000). The economics of biological invasions. UK: Edward Elgar Cheltenham., $376 \mathrm{p}$.

$\mathrm{R}$ Core Team. (2015). $R$ (Version 3.2.3).. Retrieved from https://www.R-project.org/

Seastedt, T. R. (2014). Biological control of invasive plant species: A reassessment for the anthropocene. New Phytologist, 205, 490-502.

Seebens, H., Blackburn, T. M., Dyer, E. E., Genovesi, P., Hulme, P. E., Jeschke, J. M., et al. (2017). No saturation in the accumulation of alien species worldwide. Nature Communications, 8, 14435.

Shaw, R. H., Ellison, C. A., Marchante, H., Pratt, C. F., Schaffner, U., Sforza, R. F., et al. (2018). Weed biological control in the European Union: From serendipity to strategy. BioControl, 63, 333-347.

Šikoparija, B., Skjøth, C. A., Celenk, S., Testoni, C., Abramidze, T., Alm Kübler, K., et al. (2016). Spatial and temporal variations in airborne Ambrosia pollen in Europe. Aerobiologia, 33, 181-189.

Sun, Y., Brönnimann, O., Roderick, G. K., Poltavsky, A., Lommen, S. T. E., \& Müller-Schärer, H. (2017). Climatic suitability ranking of biological control candidates: a biogeographic approach for ragweed management in Europe. Ecosphere, 8, e01731. http://dx.doi.org/10.1002/ecs2.1731

Thibaudon, M., Oliver, G., \& Cheynel, A. (2008). L'index clinique: outil d'évaluation de l'impact sanitaire du pollen. Environnement Risques \& Santé, 7, 411-416.

Thibaudon, M., Hamberger, C., Guilloux, L., \& Massot, R. (2010). Ragweed pollen in France: Origin, diffusion, exposure. European Annals of Allergy and Clinical Immunology, 42, 209-215.
Thibaudon, M., Šikoparija, B., Oliver, G., Smith, M., \& Skjøth, C. A. (2014). Ragweed pollen source inventory for France The second largest centre of Ambrosia in Europe. Atmospheric Environment, 83, 62-71.

van Wilgen, B. W., Forsyth, G. G., Le Maitre, D. C., Wannenburgh, A., Kotze, J. D. F., van den Bergand, E., et al. (2012). An assessment of the effectiveness of a large, national-scale invasive alien plant control strategy in South Africa. Biological Conservation, 148, 28-38.

Vilà, M., Espinar, J. L., Hejda, M., Hulme, P. E., Jarošík, V., Maron, et al. (2011). Ecological impacts of invasive alien plants: A metaanalysis of their effects on species, communities and ecosystems. Ecology Letters, 14, 702-708.

Zhou, Z.-S., Guo, J.-Y., Chen, H.-S., \& Wan, F.-H. (2010). Effects of temperature on survival, development, longevity and fecundity of Ophraella communa (Coleoptera: Chrysomelidae), a potential biological control agent against Ambrosia artemisiifolia (Asterales: Asteraceae). Environmental Entomology, 39, 1021-1027.

Zhou, Z.-S., Guo, J.-Y., Zheng, X.-W., Lu, M., Chen, H.-S., \& Wan, F.-H. (2011). Reevaluation of biosecurity of Ophraella communa against sunflower (Helianthus annuus). Biocontrol Science and Technology, 21, 1147-1160.

Zhou, Z.-S., Chen, H.-S., Zheng, X.-W., Guo, J.-Y., Guo, W., Li, M., et al. (2014). Control of the invasive weed Ambrosia artemisiifolia with Ophraella communa and Epiblema strenuana. Biocontrol Science and Technology, 24, 950-964. 